Kadlcorá, who shared not only his scientific interests but also his devout Protestantism, and both were interested in the Czechoslovak Student Christian Movement.

Simek, who died at the early age of fifty-five, will be sadly missed when Czechoslovakia is again liberated and the Masaryk University of Brno is ro-opened.
WE regret to announce the following deaths:

Dr. Mary Jane Rathbun, honorary associate in zoology since 1915 of the U.S. National Museum, known for her work on the Crustacea, particularly the crabs, recent and fossil, on April 4, aged eighty. two.

Mr. H. L. Sikes, C.B.E., formerly director of public works, Kenya Colony, on May 23, aged sixty-one.

\title{
BRITISH AND RUSSIAN MEN OF SCIENCE EXCHANGE OF GREETINGS
}

\begin{abstract}
$\mathrm{T}$ HE following message from Prof. Lena Stern, of the Academy of Sciences of the U.S.S.R., to British men of science was transmitted by the Embassy in London of the U.S.S.R. to the Royal Society. With the view of carrying out its intention, Sir Henry Dale, president of the Royal Society, has asked us to publish the message, so that it may reach a wide constituency of those for whom it is intended, together with the reply which he has forwarded to Prof. Stern through the Soviet Embassy.
\end{abstract}

\section{Message from Prof. Lena Stern}

On the day of the second anniversary of the War, I would like to tell you a little of how we Soviet scientists are carrying on to-day, working for our common cause of victory.

In this historic struggle of two worlds, of two world outlooks, of two diametric principles-good against evil, light against darkness, civilization against barbarity-our science has wholly devoted itself to freeing culture from the menace of Hitlerism, to defending the freedom of all nations.

Without exception, all our scientific workersyoung and old, men and women-consider it their sacred duty to give all their strength and energy, all their knowledge and their very lives for this cause; and they fulfil their duty sublimely, disregarding all difficulties and all privations which the War has brought in its wake.

The work which is being carried on so intensively at our factories and mills, in our research institutes, in our university departments and in our war hospitals is wholly directed towards helping the front, to perfecting the arms of war, to protecting the health of our fighters. Our science is closely bound up with all the manifestations of the life of the people, both at the front and behind the lines, so much so that it is impossible to divide the man of learning from the fighter, just as it is impossible to divide the research institute from the factory.

It can be said without exaggeration that the heart of the whole people beats in unison with the front and that the slogan "Everything for the front" is not mere words but an actively motivated feeling of the entire people, of our multi-national State.

It is gratifying to be able to state that the theoretical achievements of our science now find wide and successful utilization in the defence of our country and in the strengthening of the fighting powers of our army. Personally I, with my pupils and associates, have since the first days of the War bent all our strength and knowledge to solving problems of the successful treatment of wounded fighters. I am happy beyond words that the results of our many years of theoretical researches now find application in the treatment of such dangerous complications attending injuries as those of shock and tetanus, as well as in accelerating the healing of wounds and the combating of fatigue.

One feels the greatest satisfaction at knowing that by our work to-day we are bringing nearer the hour of our common victory, bringing nearer the advent of peace under which creative work will be able to develop to its full force.

We must all remember that our peaceful, con. structive endeavours, the labour of free men of science, can be ensured only by complete victory over the enemy. I believe this victory will come as the result of the joint offensive by the Allied Armies.

Warmest greetings to you, my friends.

Moscow, June 27.

LENA Stern.

Reply by Sir Henry Dale, G.B.E., F.R.S.

The receipt of your message to British men of science has given great joy, and reminded me of my friendship with you, and our work together for international science, before the enemies of mankind inflicted on the world its present miseries, by their ruthless attack on the freedom and civilization of independent peoples.

Your stirring message came to me as president of the Royal Society of London, and, on behalf of all British men of science, I most heartily reciprocate your greetings and encouragement. We send to all the scientific workers of the U.S.S.R. an assurance of our full union with them, and with the men of science of all the great alliance, in a strong and fierce determination to use the utmost measure of our knowledge, skill and devotion to ensure and hasten the utter defeat of the enemies of freedom. We are equally determined that, with that defeat, conditions shall be established beyond danger of further attack, in which the scientific men of all nations may work for the greater happiness and health of all mankind.

Tell our comrades, the scientific workers of the U.S.S.R., that we, the scientific workers of Britain and of all the British Commonwealth, have been wholeheartedly devoted to these aims and these ideals during nearly four years of war, and with continued enthusiasm and growing confidence during these two years, in which we have known that our colleagues of the U.S.S.R. were our open and devoted allies in this tremendous war for freedom. We watch with unbounded admiration the achievements of the armies, workers and men of science of the U.S.S.R. for the common cause. We rejoice to know that we are marching together for the freedom of science and of the world.

With my friendliest personal greetings to yourself, and from all British men of science to all those of the U.S.S.R.

Royal Society, July 7. 